\title{
Possible Role of Insulin Status in the Increased Lipogenic Enzyme Activity by Dietary Medium- Chain Triglyceride in Rat Liver
}

\author{
Sachiko TAKASE ${ }^{1}$ and Norimasa HOSOYA ${ }^{2}$ \\ ${ }^{1}$ Department of Foods and Nutrition, Faculty of Science of Living, \\ Shizuoka Women's University, Yada, Shizuoka 422, Japan \\ ${ }^{2}$ Department of Nutrition, School of Health Science, \\ Faculty of Medicine, The University of Tokyo, \\ Bunkyo-ku, Tokyo 113, Japan
}

(Received June 5, 1986)

\begin{abstract}
Summary The possible role of insulin status in the increase in liver lipogenic enzyme activities upon feeding medium-chain triglyceride (MCT) was investigated with streptozotocin-induced diabetic rats and insulin-treated diabetic rats. Rats were fed synthetic diets that contained either $2 \%$ corn oil (control), fat free, $13 \%$ MCT $+2 \%$ corn oil, or $13 \%$ lard $+2 \%$ corn oil, respectively. Feeding the MCT diet for 3 days increased serum ketone bodies in both the normal and diabetic rats. Insulin levels of MCT-fed rats tended to be higher than in normal animals. MCT feeding caused an enhancement of fatty acid synthetase (FAS) and malic enzyme (ME) in the liver of normàl rats, whereas diabetic rats failed to register an increase in those activities due to MCT feeding. Administration of insulin to diabetic rats resulted in a recovery of the level of those enzyme activities to about the same degree as in each of the normal rat groups. It was interesting that diabetic MCT-fed rats with insulin treatment maintained higher enzyme activities in comparison to the lard and control groups. These results suggest that the increase in lipogenic enzyme activities caused by dietary MCT is presumably dependent on differences in insulin status.
\end{abstract}

Key Words dietary MCT, lipogenic enzymes, diabetic rats, insulin administration

Short-term as well as long-term feeding of diets containing medium-chain triglyceride (MCT) induced an increase in lipogenic enzyme activities in the rat liver $(1,2)$. This enhancement was dependent on the amount of dietary MCT (2). The mechanism involved in this increase of enzyme activity remains to be

1 高瀬幸子, ${ }^{2}$ 細谷憲政 
elucidated.

It is well known that the metabolic consequences of MCT are very different from those of long-chain triglyceride (LCT) (3). MCT feeding causes increased plasma ketone bodies $(4,5)$ and insulin $(4,5)$ levels, resulting from rapid metabolization of medium-chain fatty acids to $\mathrm{CO}_{2}$ and ketone bodies in the liver (3), while LCT feeding does not. In view of these differences, the effect of MCT on the induction of lipogenic enzyme activity is of considerable interest and may relate to various MCT-induced influences on the metabolic state of animals. The MCT effect also appears to be specifically concerned with the insulin level and intermediate contents in the metabolic pathway of lipogenesis, although the effect of MCT ingestion on plasma insulin is not always consistent; some reports have indicated no effect of MCT feeding on the insulin level $(6,7)$.

On the other hand, comprehensive studies have shown that insulin is involved in the induction of lipogenic enzymes $(8-10)$. It is well known that a highcarbohydrate-fat-free diet increases lipogenic enzyme activity (11) and this could be mediated by hyperinsulinemia (9). Thus, if MCT ingestion indeed increases the plasma insulin level, then the induction of lipogenic enzyme activity by MCT feeding might be the result of insulin status.

The following study was undertaken to determine the possible role of insulin status in the enhancement of lipogenic enzyme activity in MCT-fed rat livers. Animals were first made diabetic and some of them were given insulin treatment. They were then used to evaluate MCT influence on liver lipogenic enzymes.

\section{METHODS}

Animals. Diabetes were induced in about two-third of 73 male Wistar strain rats each weighing about $170 \mathrm{~g}$ by intraperitoneal injection of streptozotocin $(50 \mathrm{mg} / \mathrm{kg})$ dissolved in citrate buffer $(\mathrm{pH} \mathrm{4.5)}$. All of the rats to be made diabetic were initially fasted for $24 \mathrm{~h}$ and then injected with the streptozotocin, followed by another $12 \mathrm{~h}$ of fasting. The rats were housed in metabolic cages and urinary volume was measured daily. The urine was tested for glucosuria using the glucose oxidase method(12). Only those rats with heavy glucosuria, which corresponds to be a blood glucose level of 300 to $500 \mathrm{mg} / \mathrm{dl}(13)$, were used for study.

The remaining rats were fasted for 2 days before being used for experimentation. All animals were given the four diets by pair-feeding for 3 days. The average daily intake of rats on the control diet was used as the bases of pair-feeding for the normal and diabetic rats, respectively. The composition of the diets is shown in Table 1. Deionized water was given ad libitum. Insulin was administered subcutaneously to half of the diabetic rats at a dose of 3 units/day per $100 \mathrm{~g}$ body weight from the beginning to the end of the refeeding period. However, the insulin dose per day was divided into two equal doses and administered at 12-h intervals.

The animals were sacrificed by decapitation between 9 and 10 a.m. Blood samples were collected and separated into serum. The livers were quickly removed, 
Table 1. Composition of experimental diets.

\begin{tabular}{lcccc}
\hline \multirow{2}{*}{ Ingredients } & \multicolumn{4}{c}{ Groups } \\
\cline { 2 - 5 } & Control & Fat-free & MCT & Lard \\
\hline Sucrose & 70 & 72 & 57 & 57 \\
Casein $^{1}$ & 20 & 20 & 20 & 20 \\
Corn oil $_{\text {MCT oil }}{ }^{2}$ & 2 & & 2 & 2 \\
Lard $_{\text {Cellulose powder }}{ }^{4}$ & 3 & 3 & 13 & 13 \\
Salt mix. $^{4}$ & 4 & 4 & 3 & 3 \\
Vitamin mix. $^{5}$ & 0.5 & 0.5 & 4 & 4 \\
Choline chloride & 0.5 & 0.5 & 0.5 & 0.5 \\
\hline
\end{tabular}

${ }^{1}$ Nutritional Biochemical, Cleveland, Ohio. ${ }^{2}$ MCT, medium-chain triglyceride. ${ }^{3}$ Toyo Roshi Co., Tokyo. ${ }^{4}$ Harper's salt mixture purchased from Oriental Yeast Co., Yokohama. ${ }^{5}$ The following vitamins were made up to a final volume of $50 \mathrm{~g}$ by adding glucose: vitamin A acetate, $434 \mathrm{mg}$; vitamin $\mathrm{D}_{2}, 65 \mathrm{mg}$; vitamin $\mathrm{E}$ acetate, $3.1 \mathrm{~g}$; vitamin $\mathrm{K}_{3}, 20 \mathrm{mg}$; niacin, $7.38 \mathrm{~g}$; inositol, $3.69 \mathrm{~g}$; pyridoxine- $\mathrm{HCl}, 260 \mathrm{mg}$; thiamine- $\mathrm{HCl}$, $260 \mathrm{mg}$; riboflavin, $260 \mathrm{mg}$; calcium pantothenate, $550 \mathrm{mg}$; $p$-aminobenzoic acid, $3 \mathrm{~g}$; ascorbic acid, $250 \mathrm{mg}$; vitamin $\mathrm{B}_{12}, 0.5 \mathrm{mg}$; biotin, $0.25 \mathrm{mg}$; folic acid, $25 \mathrm{mg}$.

rinsed with cold saline, blotted, and weighed. They were then utilized for measurements of lipogenic enzyme activities in the soluble supernatant fraction.

Enzyme assay. A portion of each liver weighing approximately $4 \mathrm{~g}$ was homogenized with 2.5 volumes of $0.1 \mathrm{M}$ potassium phosphate buffer ( $\mathrm{pH}$ 7.4) containing $0.25 \mathrm{M}$ sucrose, $0.07 \mathrm{M} \mathrm{KHCO}_{3}, 1 \mathrm{~mm}$ EDTA, and $1 \mathrm{~mm}$ dithiothreitol in a glass-Teflon homogenizer. The homogenate was centrifuged at $8,000 \times g$ for $20 \mathrm{~min}$ and the resulting postmitochondrial supernatant was centrifuged at $105,000 \times g$ for $60 \mathrm{~min}$. The clear supernatant was used for the enzyme assays.

Fatty acid synthetase and malic enzyme [EC 1.1.1.40] were assayed spectrophotometrically according to the procedures described by Muto and Gibson (14). The concentration of protein in the enzyme source was determined by the method of Lowry et al. (15) using bovine serum albumin as a standard.

Determinations. A portion of the serum was immediately analyzed for glucose by the glucose oxidase method using a Glucostat. The urine glucose was also measured by the same procedure. Serum insulin was immunologically assayed essentially according to the method of Hales and Randle (16). Serum ketone bodies were measured fluorometrically by a modification of the method described by Bates et al. (17). Free fatty acid levels in serum were measured according to Novák (18).

Statistics. Data were analyzed by a two-way analysis of variance. When a significant effect of diets was obtained, further comparisons among groups were done using the Student's $t$-test procedure. 
Chemicals. MCT composed of trioctanoate (based on gas-liquid chromatography analysis) was kindly provided by Nissin Oil Manufacture Co., Yokohama, corn oil by Honen Oil Manufacture Co., Shimizu, and lard produced by Snow Brand Milk Productory Co., Tokyo was purchased. Lente insulin, slow-acting insulin, was obtained from Lily Co., Indianapolis, In. Streptozotocine was obtained from Sigma Chemical Co., St. Louis, Mo., and Glucostat from Yatoron Chemical Co., Tokyo. Other chemicals used were of analytical grade.

\section{RESULTS}

Body weight gains were not significantly different among the 4 groups of normal and diabetic rats, although the body weight gain of diabetic rats was less than that of normal rats (Table 2). Physiological parameters in the serum are shown in Table 3. The serum glucose levels were $442-453 \mathrm{mg} / \mathrm{dl}$ in diabetic rats. The levels of serum insulin in the diabetic rat groups were markedly lower than in the normal groups. MCT feeding tended to increase the insulin level in normal animals. Even diabetic rats of the MCT group showed such a tendency compared to the other diet groups, although the level was not statistically significant.

In normal rats, the increase due to MCT feeding in lipogenic enzyme acitivities was similar to that shown previously (Table 4) $(1,2)$. Enzyme activities in the diabetic rats in all 4 groups were dampened drastically, and MCT feeding failed to increase these enzyme activities (Table 4). That is, the levels of FAS and ME

Table 2. Body weight gains and food intake.

\begin{tabular}{lcccc}
\hline & $\begin{array}{c}\text { Rat } \\
\text { no. }\end{array}$ & $\begin{array}{c}\text { Body weight } \\
(\mathrm{g})\end{array}$ & $\begin{array}{c}\text { Weight gain } \\
(\mathrm{g} / 3 \text { days })\end{array}$ & $\begin{array}{c}\text { Food intake } \\
\mathrm{g} / \text { day })\end{array}$ \\
\hline Normal & & & & \\
$\quad$ Control & $(6)$ & $143 \pm 2$ & $18 \pm 6$ & $14.6 \pm 0.3$ \\
Fat-free & $(8)$ & $146 \pm 2$ & $17 \pm 2$ & $14.4 \pm 0.6$ \\
MCT & $(8)$ & $145 \pm 1$ & $20 \pm 3$ & $13.8 \pm 0.3$ \\
Lard & $(6)$ & $145 \pm 2$ & $19 \pm 2$ & $13.6 \pm 0.2$ \\
Diabetic & & & & \\
Control & $(6)$ & $149 \pm 5$ & $-10 \pm 1$ & $14.0 \pm 1.0$ \\
Fat-free & $(6)$ & $143 \pm 3$ & $-8 \pm 3$ & $14.5 \pm 2.9$ \\
MCT & $(7)$ & $147 \pm 2$ & $-4 \pm 2$ & $14.2 \pm 2.6$ \\
Lard & $(6)$ & $146 \pm 2$ & $-6 \pm 2$ & $13.5 \pm 0.9$ \\
Insulin-administered diabetic & & & & \\
Control & $(5)$ & $148 \pm 4$ & $16 \pm 4$ & $13.9 \pm 1.1$ \\
Fat-free & $(5)$ & $143 \pm 2$ & $18 \pm 3$ & $13.4 \pm 2.7$ \\
MCT & $(5)$ & $145 \pm 3$ & $16 \pm 2$ & $11.2 \pm 1.2$ \\
Lard & $(5)$ & $153 \pm 2$ & $17 \pm 3$ & $13.3 \pm 0.9$ \\
\hline
\end{tabular}

Body weights of animals at the start of refeeding. Data are expressed as means \pm SEM. 
Table 3. Levels of glucose, free fatty acids, ketone bodies, and insulin in the serum of normal and diabetic rats.

\begin{tabular}{lccccc}
\hline & $\begin{array}{c}\text { Rat } \\
\text { no. }\end{array}$ & $\begin{array}{c}\text { Glucose } \\
(\mathrm{mg} / \mathrm{dl})\end{array}$ & $\begin{array}{c}\text { Free fatty acids } \\
(\mu \mathrm{Eq} / \mathrm{dl})\end{array}$ & $\begin{array}{c}\text { Ketone bodies } \\
(\mathrm{mmol} / \mathrm{liter})\end{array}$ & $\begin{array}{c}\text { Insulin } \\
(\mu \mathrm{U} / \mathrm{ml})\end{array}$ \\
\hline Normal & & & & & \\
Control & $(6)$ & $134 \pm 10^{\mathrm{a}}$ & $237 \pm 33^{\mathrm{a}}$ & $0.10 \pm 0.01^{\mathrm{a}}$ & $26.3 \pm 2.3^{\mathrm{a}}$ \\
Fat-free & $(8)$ & $139 \pm 12^{\mathrm{a}}$ & $267 \pm 14^{\mathrm{a}}$ & $0.13 \pm 0.04^{\mathrm{a}}$ & $29.3 \pm 1.0^{\mathrm{b}}$ \\
MCT & $(8)$ & $147 \pm 6^{\mathrm{a}}$ & $317 \pm 58^{\mathrm{a}}$ & $0.44 \pm 0.18^{\mathrm{b}}$ & $34.0 \pm 2.4^{\mathrm{b}}$ \\
Lard & $(6)$ & $140 \pm 8^{\mathrm{a}}$ & $251 \pm 28^{\mathrm{a}}$ & $0.12 \pm 0.02^{\mathrm{a}}$ & $27.0 \pm 2.9^{\mathrm{ab}}$ \\
Diabetic & & & & & \\
Control & $(6)$ & $410 \pm 18^{\mathrm{b}}$ & $485 \pm 38^{\mathrm{b}}$ & $0.45 \pm 0.3^{\mathrm{c}}$ & $8.1 \pm 1.5^{\mathrm{c}}$ \\
Fat-free & $(6)$ & $442 \pm 14^{\mathrm{b}}$ & $500 \pm 57^{\mathrm{b}}$ & $0.36 \pm 0.24^{\mathrm{c}}$ & $7.8 \pm 1.6^{\mathrm{c}}$ \\
MCT & $(7)$ & $453 \pm 19^{\mathrm{b}}$ & $867 \pm 62^{\mathrm{c}}$ & $2.85 \pm 0.38^{\mathrm{d}}$ & $14.4 \pm 4.5^{\mathrm{c}}$ \\
Lard & $(6)$ & $427 \pm 16^{\mathrm{b}}$ & $511 \pm 61^{\mathrm{b}}$ & $0.41 \pm 0.12^{\mathrm{bc}}$ & $8.5 \pm 2.0^{\mathrm{c}}$ \\
& & & Analysis of variance, $p$-value & \\
Diet & & $\mathrm{NS}$ & 0.01 & 0.01 & 0.01 \\
Animals & & 0.01 & 0.01 & 0.01 & 0.01 \\
Diet $\times$ animal status & $\mathrm{NS}$ & 0.01 & 0.01 & 0.01 \\
\hline
\end{tabular}

Data are expressed as means \pm SEM. Values with different superscripts in a column are significantly different at $p<0.05$. NS, no significant effect.

in MCT-fed diabetic rats were the same as those of the groups fed on the fat-free or lard diets.

With insulin treatment, the diabetic rats fed each of the 4 diets showed elevated activities of FAS and ME that nearly reached the levels of normal rats (Table 4). However, despite the administration of an equal amount of insulin, there were still higher activities of FAS and ME in the livers of MCT-fed rats than in rats fed the control or lard diets. On the other hand, there were no notable differences in these activities between rats fed the fat-free or MCT diets. Despite the addition of $2 \%$ corn oil, a substance recognized to induce a lowering effect on the lipogenic enzyme activity (2), to the MCT diet the FAS and ME activities were not lower in the MCT group than in the fat-free insulin-treated diabetic rats. Among the insulin-treated diabetic rats, the lard group showed lower activities of FAS and ME than the fatfree group. In addition, in the control group fed the $2 \%$ corn oil diet, these enzyme activities were suppressed compared to the fat-free group in the normal and insulintreated diabetic rats. Therefore, adding $2 \%$ corn oil to the MCT diet was not effective in depressing these enzyme activities in either the normal or insulin-treated diabetic rats.

\section{DISCUSSION}

The data reported here confirmed an increase in the level of serum ketone Vol. 33, No. 3, 1987 
Table 4. Effect of MCT feeding on liver lipogenic enzyme activity in diabetic and insulin-administered diabetic rats.

\begin{tabular}{|c|c|c|c|}
\hline & \multirow{2}{*}{$\begin{array}{l}\text { Rat } \\
\text { no. }\end{array}$} & \multicolumn{2}{|c|}{ Activity of } \\
\hline & & $\begin{array}{l}\text { Fatty acid synthetase } \\
\qquad(\mathrm{nmol} / \mathrm{min} / \mathrm{m}\end{array}$ & $\begin{array}{l}\text { Malic enzyme } \\
\text { tein) }\end{array}$ \\
\hline \multicolumn{4}{|l|}{ Normal } \\
\hline Control & (6) & $21.0 \pm 2.1^{\mathrm{a}}$ & $121 \pm 12^{\mathrm{a}}$ \\
\hline Fat-free & $(8)$ & $39.9 \pm 7.8^{\mathrm{b}}$ & $182 \pm 15^{b}$ \\
\hline MCT & (8) & $58.0 \pm 6.0^{\mathrm{b}}$ & $225 \pm 37^{b}$ \\
\hline Lard & (6) & $27.8 \pm 3.3^{\mathrm{ad}}$ & $112 \pm 12^{\mathrm{a}}$ \\
\hline \multicolumn{4}{|l|}{ Diabetic } \\
\hline Control & (6) & $5.4 \pm 1.4^{\mathrm{c}}$ & $12 \pm 1^{\mathrm{c}}$ \\
\hline Fat-free & (6) & $3.4 \pm 3.0^{\mathrm{c}}$ & $12 \pm 2^{\mathrm{c}}$ \\
\hline MCT & (7) & $6.6 \pm 2.3^{c}$ & $22 \pm 2^{c}$ \\
\hline Lard & (6) & $6.3 \pm 1.0^{\mathrm{c}}$ & $26 \pm 4^{c}$ \\
\hline \multicolumn{4}{|c|}{ Insulin-administered diabetic } \\
\hline Control & $(5)$ & $33.6 \pm 1.8^{\mathrm{d}}$ & $124 \pm 10^{\mathrm{a}}$ \\
\hline Fat-free & (5) & $55.7 \pm 7.7^{\mathrm{b}}$ & $218 \pm 29^{b}$ \\
\hline MCT & (5) & $52.4 \pm 5.1^{\mathrm{b}}$ & $220 \pm 18^{b}$ \\
\hline \multirow[t]{2}{*}{ Lard } & $(5)$ & $35.0 \pm 4.4^{\mathrm{d}}$ & $108 \pm 9^{a}$ \\
\hline & & \multicolumn{2}{|c|}{ Analysis of variance, $p$-value } \\
\hline Diet & & 0.01 & 0.01 \\
\hline Animal status & & 0.01 & 0.01 \\
\hline Diet $\times$ animal status & & 0.01 & 0.01 \\
\hline
\end{tabular}

Data are expressed as means \pm SEM. Values with different superscripts in a column are significantly different at $p<0.05$.

bodies in MCT-fed rats, most notably in diabetic rats fed MCT. This is consistent with other reports $(4,5)$. Previous observations have reported that ketone bodies stimulate insulin release $(4,5,19)$. MCT feeding showed a tendency to enhance serum insulin levels in normal animals. This tendency appears in part to be responsible for the high FAS and ME activities in the livers of rats fed a MCT diet.

On the other hand, the insulin status of rats contributed to the elevation of activities of lipogenic enzymes during MCT feeding (Table 4). An important observation was that the effect of dietary MCT on lipogenic enzymes was not prevalent in insulin depletion. In contrast, the administration of insulin to diabetic rats fed MCT triggered a drastic increase in lipogenic enzyme activity. Even when insulin was administered to the 4 groups of diabetic rats, FAS and ME activities in MCT-fed rats increased far more than in rats fed the control or lard diets (Table 4). Furthermore, as compared with the fat-free diet, the MCT diet containing $2 \%$ corn oil did not lead to lower activities of those enzymes in insulin-treated diabetic rats. The MCT group received even less carbohydrate than the fat-free group, and 
consumed about the same amount as did the lard group. These results reinforced the previous conclusion $(1,2)$ that MCT feeding enhances lipogenic enzyme activities by a mechanism(s) that remains to be elucidated.

It is probable that insulin status is one of the factors contributing to the MCT effect. It is also conceivable that in an insulin-sufficient status, MCT feeding may accelerate the production of some intermediary metabolites necessary for lipid synthesis. These could in turn, directly or indirectly, enhance lipogenic enzyme activities. If insulin mediates in the production of such intermediary metabolites, an expression of the increase due to dietary MCT will depend on differences in insulin status. Such a dependency was observed (Table 4).

Presumably the lipogenic enzyme level is maintained by regulation of the rates of enzyme synthesis and degradation $(20,21)$. The stimulus for maintaining the levels of lipogenic enzymes may be greatly dependent upon hormonal status, which is extremely sensitive to nutrient intake (21). Perhaps the delicate balance between the insulin and glucagon levels is involved in the maintenance of a high rate of fatty acid synthesis. It is known that hepatic lipogenesis is sensitive to glucagon, which decreases the activities of lipogenic enzymes $(8,22)$. Although glucagon levels were not determined in this study, the possibility that an increase in the insulin/glucagon ratio in the serum of rats fed the MCT diet may occur should not be ruled out.

The data reported here indicate that the effect of dietary MCT in increasing lipogenic enzyme activities was more pronounced in insulin-sufficient, rather than -deficient, animals. In order to more fully understand the mechanism(s) of this effect, further investigation is needed.

\section{REFERENCES}

1) Takase, S., Morimoto, A., Nakanishi, M., and Muto, Y. (1977): Long-term effect of medium chain triglyceride on hepatic enzymes catalyzing lipogenesis and cholesterogenesis in rats. J. Nutr. Sci. Vitaminol., 23, 43-51.

2) Takase, S., and Hosoya, N. (1986): Effect of dietary medium chain triglyceride on lipogenic enzyme activity in rat liver. J. Nutr. Sci. Vitaminol., 32, 219-227.

3) Greenberger, N. J., and Skillman, T. G. (1969): Medium-chain triglycerides. Physiologic considerations and clinical implications. New Engl. J. Med., 280, 1045-1058.

4) Wiley, J. H., and Leveille, G. A. (1973): Metabolic consequences of dietary medium chain triglycerides in the rat. J. Nutr., 103, 829-835.

5) Yeh, Y-Y., and Zee, P. (1976): Relation of ketosis to metabolic changes induced by acute medium chain triglyceride feeding in rats. J. Nutr., 106, 58-67.

6) Lavau, M. M., and Hashim, S. A. (1978): Effect of medium chain triglyceride on lipogenesis and body fat in the rat. $J$. Nutr., 108, 613-620.

7) Guy, D. G., and Tuley, R. J., Jr. (1981): Effect of diets high in carbohydrate, soy oil, medium chain triglycerides or tripelargonin on blood and liver lipid and glucose intermediates in meal-eating rats. J. Nutr., 111, 1437-1445.

8) Lakshmanan, M. R., Nepokroeff, C. M., and Porter, J. W. (1972): Control of the synthesis of fatty-acid synthetase in rat liver by insulin, glucagon, and adenosine $3^{\prime}, 5^{\prime}$ cyclic monophosphate. Proc. Natl. Acad. Sci. USA, 69, 3516-3519. 
9) Green, M. J. H., Harris, R. A., Beynen, A. C., and McCune, S. A. (1980): Short-term hormonal control of hepatic lipogenesis. Diabetes, 29, 1006-1022.

10) Spence, J. T., and Pitot, H. C. (1982): Induction of lipogenic enzymes in primary cultures of rat hepatocytes. Relationship between lipogenesis and carbohydrate metabolism. Eur. J. Biochem., 128, 15-20.

11) Allman, D. W., and Gibson, D. M. (1965): Fatty acid synthesis during early linoleic acid deficiency in the mouse. J. Lipid Res., 6, 51-62.

12) Dahlqvist, A. (1964): Method for assay of intestinal disaccharidases. Anal. Biochem., 7 , $18-25$.

13) Caspary, W. F., Rhein, A. M., and Creutzfeldt, W. (1972): Increase of intestinal brush border hydrolases in mucosa of streptozotocin-diabetic rats. Diabetologia, 8, 412-414.

14) Muto, Y., and Gibson, D. M. (1970): Selective dampening of lipogenic enzymes of liver by exogenous polyunsaturated fatty acids. Biochem. Biophys. Res. Commun., 38, 9-15.

15) Lowry, O. H., Rosebrough, N. J., Farr, A. L., and Randall, R. J. (1951): Protein measurement with the Folin phenol reagent. J. Biol. Chem., 193, 265-275.

16) Hales, C. N., and Randle, P. J. (1963): Immunoassay of insulin-antibody precipitate. Biochem. J., 88, 137-146.

17) Betes, M., Krebs, H., and Williamson, D. H. (1968): Turnover rates of ketone bodies in normal; starved and alloxan diabetic rats. Biochem. J., 110, 655-661.

18) Novák, M. (1965): Colorimetric ultramicro method for the determination of free fatty acids. J. Lipid Res., 6, 431-433.

19) Malaisse, W. J., and Malaisse-Lagae, F. (1968): Stimulation of insulin secretion by noncarbohydrate metabolites. J. Lab. Clin. Med., 72, 438-448.

20) Flick, P. K., Chen, J., and Vagelos, R. R. (1977): Effect of dietary linoleate on synthesis and degradation of fatty acid synthetase from rat liver. J. Biol. Chem., 252, 4242-4249.

21) Edozien, J. C., Niehaus, N., Mar, M. H., Makoui, T., and Switzer, B. R. (1978): Diethormone interrelationships in the rat. J. Nutr., 108, 1767-1776.

22) Beynen, A. C., Vaartjes, W. J., and Greelen, M. J. H. (1979): Opposite effects of insulin and glucagon in acute hormonal control of hepatic lipogenesis. Diabetes, 28, 828-835. 